\title{
Association of UDP-galactose-4-epimerase with milk protein concentration in the Chinese Holstein population
}

\author{
Cong $\mathrm{Li}^{1}$, Wentao Cai ${ }^{2}$, Shuli Liư ${ }^{2}$, Chenghao Zhou ${ }^{2}$, Mingyue $\mathrm{Cao}^{2}$, Hongwei Yin², \\ Dongxiao Sun ${ }^{2}$, Shengli Zhang ${ }^{2, *}$, and Juan J. Loor ${ }^{3, *}$
}

\author{
* Corresponding Authors: \\ Shengli Zhang \\ Tel: +86-010-62733967, Fax: +86-010-62733967, \\ E-mail: zhangslcau@cau.edu.cn \\ Juan J. Loor \\ Tel: +1-217-244-5957, Fax: +1-217-333-5044, \\ E-mail: loor@illinois.edu \\ 'Shaanxi Key Laboratory of Molecular Biology \\ for Agriculture, College of Animal Science and \\ Technology, Northwest A\&F University, Yangling, \\ Shaanxi 712100, China \\ ${ }^{2}$ College of Animal Science and Technology, Key \\ Laboratory of Animal Genetics and Breeding of \\ Ministry of Agriculture, National Engineering \\ Laboratory for Animal Breeding, China Agricultural \\ University, Beijing 100193, China \\ ${ }^{3}$ Mammalian NutriPhysioGenomics, Department of \\ Animal Sciences and Division of Nutritional Sciences, \\ University of Illinois, Urbana, IL 61801, USA \\ ORCID \\ Cong Li \\ https://orcid.org/0000-0003-2588-4781 \\ Wentao Cai \\ https://orcid.org/0000-0002-5639-1755 \\ Shuli Liu \\ https://orcid.org/0000-0001-5933-2374 \\ Chenghao Zhou \\ https://orcid.org/0000-0002-4539-1979 \\ Mingyue Cao \\ https://orcid.org/0000-0001-5924-6038 \\ Hongwei Yin \\ https://orcid.org/0000-0002-9373-5166 \\ Dongxiao Sun \\ https://orcid.org/0000-0002-7512-5946 \\ Shengli Zhang \\ https://orcid.org/0000-0002-9780-515X \\ Juan J. Loor \\ https://orcid.org/0000-0003-1586-4365
}

Submitted Jul 8, 2019; Revised Sept 29, 2019; Accepted Feb 14, 2020
Objective: An initial RNA-Sequencing study revealed that UDP-galactose-4-epimerase (GALE) was one of the most promising candidates for milk protein concentration in Chinese Holstein cattle. This enzyme catalyzes the interconversion of UDP-galactose and UDP-glucose, an important step in galactose catabolism. To further validate the genetic effect of GALE on milk protein traits, genetic variations were identified, and genotypes-phenotypes associations were performed.

Methods: The entire coding region and the 5'-regulatory region (5'-UTR) of GALE were re-sequenced using pooled DNA of 17 unrelated sires. Association studies for five milk production traits were performed using a mixed linear animal model with a population encompassing 1,027 Chinese Holstein cows.

Results: A total of three variants in GALE were identified, including two novel variants (g.2114 A $>$ G and g.2037 G>A) in the 5'-UTR and one previously reported variant (g.3836 $\mathrm{G}>\mathrm{C}$ ) in an intron. All three single nucleotide polymorphisms (SNPs) were associated with milk yield $(\mathrm{p}<0.0001)$, fat yield $(\mathrm{p}=0.0006$ to $<0.0001)$, protein yield $(\mathrm{p}=0.0232$ to $<0.0001)$ and protein percentage $(\mathrm{p}<0.0001)$, while no significant associations were detected between the SNPs and fat percentage. A strong linkage disequilibrium $\left(D^{\prime}=0.96\right.$ to 1.00$)$ was observed among all three SNPs, and a $5 \mathrm{~Kb}$ haplotype block involving three main haplotypes with GAG, AGC, and AGG was formed. The results of haplotype association analyses were consistent with the results of single locus association analysis $(\mathrm{p}<0.0001)$. The phenotypic variance ratio above $3.00 \%$ was observed for milk protein yield that was explained by SNP-g.3836G >C.

Conclusion: Overall, our findings provided new insights into the polymorphic variations in bovine GALE gene and their associations with milk protein concentration. The data indicate their potential uses for marker-assisted breeding or genetic selection schemes.

Keywords: Milk Protein Traits; GALE Gene; Genetic Effect; Haplotype; Dairy Cattle

\section{INTRODUCTION}

Milk proteins are important nutrients and milk protein concentration serves as valuable index for milk quality. Dairy industry concerns have driven increasing efforts to improve milk protein concentration [1]. With the development of genomics, bioinformatics and statistical genetics, a single gene or chromosome segments affecting important economic traits can be analyzed [2]. It is possible to improve milk protein concentration through marker assisted selection (MAS) or genomic selection schemes, the challenge, however, is to identify key genes or causal variations affecting milk protein traits [3-6]. Our previously published research has identified that UDP-galactose-4-epimerase (GALE) was a strong candidate gene for milk protein traits due to its large differential expression $\left(\log _{2}\right.$ fold-change $=-0.74$, 
$q$-value $=4.41 \mathrm{E}-03)$ in mammary tissues of cows with high and low milk protein percentage [7]. In addition, strong interactions were also observed between GALE and several other genes such as lactalbumin, alpha (LALBA), beta 1,4galactosyltransferase, polypeptide 1 (B4GALT1), and UDPglucose 6-dehydrogenase (UGDH) that play important roles in milk composition synthesis (Supplementary Figure S1) [8-10]. Therefore, based on the biological function and transcriptional effects on milk protein traits, the current study mined to screen the full-length coding regions of the GALE gene for single nucleotide polymorphisms (SNPs) and to evaluate the genetic effects of polymorphisms on milk production traits in a large Chinese Holstein population.

\section{MATERIALS AND METHODS}

\section{Ethics statement}

Animal handling and sample collection procedures were performed in accordance with protocols approved by the Institutional Animal Care and Use Committee (IACUC) at China Agricultural University (Permit Number: DK996).

\section{Genetic sampling}

A total of 1,027 Chinese Holstein cows and their 17 corresponding sires were considered as the study population. Cows were selected from 17 farms in the Beijing Sanyuan Lvhe Dairy Farm Center, where routine standard performance test, i.e. Dairy Herd Improvement system (DHI) has been implemented since 1999. The phenotype observations for all individuals for five milk production traits ( $305 \mathrm{~d}$ milk yield, $305 \mathrm{~d}$ protein yield, $305 \mathrm{~d}$ fat yield, average $305 \mathrm{~d}$ protein percentage and average $305 \mathrm{~d}$ fat percentage) were collected for subsequent analyses via the complete DHI data from the Chinese dairy cattle population.

\section{Single nucleotide polymorphism identification and genotyping}

Blood samples were collected from 1,027 cows via coccygeal vein to isolate genomic DNA using DP (318) Blood DNA kits (TianGen, Beijing, China). Genomic DNA were also isolated from frozen semen of 17 sires using standard phenol-chloroform procedures and were pooled with $50 \mathrm{ng} / \mu \mathrm{L}$ DNA of each individual to identify variants of the GALE gene. GALE gene is 4,591 bp in length located at BTA2, contains 11 exons and 10 introns encoding 348 amino acids. All exons and their adjacent intronic sequences were targeted for selective amplification by polymerase chain reaction (PCR). A total of 12 pairs of nucleotide primers (Supplementary Table S1) targeting the regions of interest were designed using Primer 3 based on the genomic sequence of the bovine GALE gene referring to Bos_taurus_UMD_3.1 assembly (NCBI reference sequence: AC_000159.1).
The PCR amplification was performed in a total volume of $25 \mu \mathrm{L}$ containing 50 to $100 \mathrm{ng}$ of genomic DNA, $0.5 \mu \mathrm{L}$ of each primer, $2.5 \mathrm{mM}$ of dNTP mix, $2.5 \mu \mathrm{L}$ of $10 \times$ PCR buffer, and $1 \mathrm{U}$ of Taq DNA Polymerase (Takara Biotechnology Co., Ltd, Dalian, China). The PCR reaction conditions included a pre-denaturation at $95^{\circ} \mathrm{C}$ for $5 \mathrm{~min}$, followed by 34 cycles of $94^{\circ} \mathrm{C}$ for $30 \mathrm{~s}$, annealing from $46^{\circ} \mathrm{C}$ to $56^{\circ} \mathrm{C}$ for $30 \mathrm{~s}, 72^{\circ} \mathrm{C}$ for $30 \mathrm{~s}$, and a final extension at $72^{\circ} \mathrm{C}$ for $10 \mathrm{~min}$. The PCR products were directly sequenced using the ABI3730xl DNA analyzer (Applied Biosystems, Foster City, CA, USA), and the sequences aligned to the bovine reference sequence (UMD3.1.1) using BLAST (http://blast.ncbi.nlm.nih.gov/ Blast.cgi) to identify potential SNPs.

The details of novel SNPs that were identified in the present study were submitted to dbSNP (http://www.ncbi.nlm. nih.gov/SNP/) and are publicly available (accession numbers from ss1996900612 to ss1996900613). All identified SNPs for subsequent genotyping in the 1,027 Chinese Holstein cows were performed with matrix-assisted laser desorption/ionization time of flight mass spectrometry (MALDI-TOF MS, Squenom MassARRAY, Bioyong Technologies Inc. Hong Kong, China) assay.

\section{Linkage disequilibrium analysis}

Haploview [11] was used to measure pairwise linkage disequilibrium (LD) for all identified SNPs within GALE. Briefly, missing genotypes were first imputed for each individual using the Beagle3.2 software program [12]. Subsequently, the LD blocks were generated with the subject genotype data using the LD coefficient (D') [13]. A haplotype with a frequency $>5 \%$ was considered as a distinguishable haplotype, while the haplotypes with relative frequency $<5 \%$ were pooled into a single group. Haplotype blocks within these SNPs were used to test their associations with milk production traits.

\section{Association analyses}

A goodness-of-fit test (Chi-square) was applied to compare the numbers of expected and observed genotypes to test Hardy-Weinberg equilibrium for each identified SNP, 0.05 as the significant threshold value. Association analyses were conducted to estimate the effects of GALE variants on milk production traits based on both single SNP genotypes and the haplotype blocks. The effects of single SNP or haplotypes in GALE on the five milk production traits were analyzed with the mixed procedure of SAS9.3 software (SAS Institute Inc., Cary, NC, USA) using the following mixed linear animal model:

$$
\mathrm{y}_{\mathrm{ijk} k m n}=\mu+F_{i}+Y S_{j}+P_{k}+\mathrm{b} \times \mathrm{M}+G_{l}+\alpha_{\mathrm{m}}+\mathrm{e}_{\mathrm{ijklmn}}
$$

where, $y_{\mathrm{ijklmn}}$ was the phenotypic value of each trait for each cow ( $\mathrm{n}=1,027$ for each trait); $\mu$ was the overall mean; $F_{i}$ was 
the fixed effect of farm; $Y S_{j}$ was the fixed effect of year-season; $P_{k}$ was the fixed effect of parity; $M$ was the covariate effect of calving month; b was the regression coefficient of $\mathrm{M} ; G_{l}$ was the fixed effect corresponding to the genotype of polymorphisms or haplotype (genotypes of SNPs were modelled as $0-1-2$, haplotypes were modelled as $0-5) ; \alpha_{m}$ was the random polygenic effect, distributed as $\mathrm{N}\left(0, A \sigma_{\mathrm{a}}^{2}\right)$, with the additive genetic relationship matrix $\mathrm{A}$ and the additive genetic variance $\sigma_{a}^{2}$; A-matrix was constructed by tracing the pedigree back to three generations of 2,312 involved individuals; and $\mathrm{e}_{\mathrm{ijklmn}}$ was the random residual, distributed as $\mathrm{N}\left(0, \mathrm{I \sigma}_{\mathrm{e}}{ }^{2}\right)$, with identity matrix I and residual error variance $\sigma_{\mathrm{e}}^{2}$.

For single SNP and haplotype analyses, the Bonferroni method was adopted to correct for multiple-testing according to the number of SNP loci or haplotype blocks. Associations were considered as significant if a raw $p$ value $<0.05 / \mathrm{N}$, where $\mathrm{N}$ was the number of SNP loci or haplotype blocks tested in analyses. The additive (a), dominance (d), and allele substitution $(\alpha)$ effects were estimated using the equation from Falconer and Mackay [14], i.e. $\mathrm{a}=(\mathrm{AA}-\mathrm{BB}) 2, \mathrm{~d}=\mathrm{AB}-(\mathrm{AA}+$ $\mathrm{BB} / 2$, and $\alpha=\mathrm{a}+\mathrm{d}(\mathrm{q}-\mathrm{p})$, where $\mathrm{AA}$ and $\mathrm{BB}$ represented the two homozygous genotypes, $\mathrm{AB}$ was heterozygous genotype, and $\mathrm{p}$ and $\mathrm{q}$ were the allele frequencies of corresponding loci.

The effect of a SNP on a specific trait was measured as the proportion of phenotypic variance of the trait explained by the SNP. The proportion of variance explained by a SNP was calculated as $2 p(1-p) \alpha^{2} / \sigma_{p}^{2}$, where $p$ was the allele frequency of SNP, $\alpha$ was the average effect of gene substitution calculated based on the linear mixed model, and $\sigma_{p}^{2}$ was the estimate of phenotypic variance using the complete DHI data of the Chinese dairy cattle population.

\section{RESULTS}

A total of three SNPs were discovered in the GALE gene of which two (g.2114A>G and g.2037G >A) in the 5'-UTR are novel (ss1996900612 and ss1996900613). The other SNP (g.3836G>C) previously reported was located in the intronic region (rs211659075) (Table 1). All three SNPs were in HardyWeinberg equilibrium ( $p>0.05$, Table 2 ).

The association results between the identified SNPs in GALE and five milk production traits are presented in Table 3. All three SNPs (g.2114A>G, g.2037G $>$ A and g.3836G $>C$ ) were highly associated with milk yield $(\mathrm{p}<0.0001)$, fat yield ( $\mathrm{p}=0.0006$ to $<0.0001)$, protein yield $(\mathrm{p}=0.0232$ to $<0.0001)$, and protein percentage $(\mathrm{p}<0.0001)$. No significant associations were observed between the SNPs and milk fat percentage. Greater than $1 \%$ of phenotypic variation accounted for by the three SNPs was detected in six significant SNP-trait pairs. Within these pairs, the pairs of g.3836G $>C$ and milk yield, g.3836G $>\mathrm{C}$ and milk protein yield and g.3836G $>\mathrm{C}$ and milk protein percentage accounted for up to $2.61 \%, 3.00 \%$, and $1.08 \%$ of phenotypic variation, respectively. In addition, significant additive effects, dominant effects and allele substitution effects were observed for the significant related traits (Table 4).

The specific LD results are showed in Supplementary Table S2-S3 and Supplementary Figure S2. Strong $L D\left(D^{\prime}=0.96\right.$ to 1.00) was observed between the three identified SNPs. A $5 \mathrm{~Kb}$ haplotype block was inferred (Figure 1), and three major

Table 1. Information for the three identified single nucleotide polymorphisms in UDP-galactose-4-epimerase gene

\begin{tabular}{lcccccc}
\hline CHR & RefSNP & SNP locus & Alleles & Location & Position & Gene \\
\hline 2 & ss1996900612 & g.2114A $>$ G & A/G & 5'-UTR & 129705167 & GALE \\
2 & ss1996900613 & g.2037G $>$ A & G/A & 5'-UTR & 129705244 & GALE \\
2 & rs211659075 & g.3836G $>$ C & G/C & Intron-9 & 129711117 & GALE \\
\hline
\end{tabular}

SNPs, single nucleotide polymorphisms; GALE, UDP-galactose-4-epimerase.

Table 2. Genotypic and allelic frequencies and Hardy-Weinberg equilibrium test of three single nucleotide polymorphisms of UDP-galactose-4-epimerase gene in Chinese Holstein cattle

\begin{tabular}{|c|c|c|c|c|c|c|c|}
\hline Position & Locus & Genotypes & $\mathrm{N}$ & Frequency & Allele & Frequency & $\begin{array}{l}\text { Hardy-Weinberg } \\
\text { equilibrium } \chi^{2} \text { test }\end{array}$ \\
\hline \multirow[t]{3}{*}{ 5'flanking region } & ss1996900612 & $A G$ & 457 & 0.454 & $A$ & 0.350 & $p>0.05$ \\
\hline & g. $2114 A>G$ & $\mathrm{AA}$ & 124 & 0.123 & G & 0.650 & \\
\hline & & GG & 425 & 0.422 & & & \\
\hline \multirow[t]{3}{*}{ 5'flanking region } & ss1996900613 & $A G$ & 491 & 0.483 & $A$ & 0.594 & $p>0.05$ \\
\hline & g.2037G >A & $\mathrm{AA}$ & 358 & 0.352 & G & 0.406 & \\
\hline & & GG & 167 & 0.164 & & & \\
\hline \multirow[t]{3}{*}{ Intron-9 } & rs211659075 & CG & 326 & 0.323 & $C$ & 0.198 & $p>0.05$ \\
\hline & g.3836G >C & $\mathrm{CC}$ & 37 & 0.037 & G & 0.802 & \\
\hline & & $\mathrm{GG}$ & 645 & 0.640 & & & \\
\hline
\end{tabular}


Table 3. Associations of UDP-galactose-4-epimerase single nucleotide polymorphisms with milk production traits in Chinese Holstein cattle (LSM $\pm S E$ )

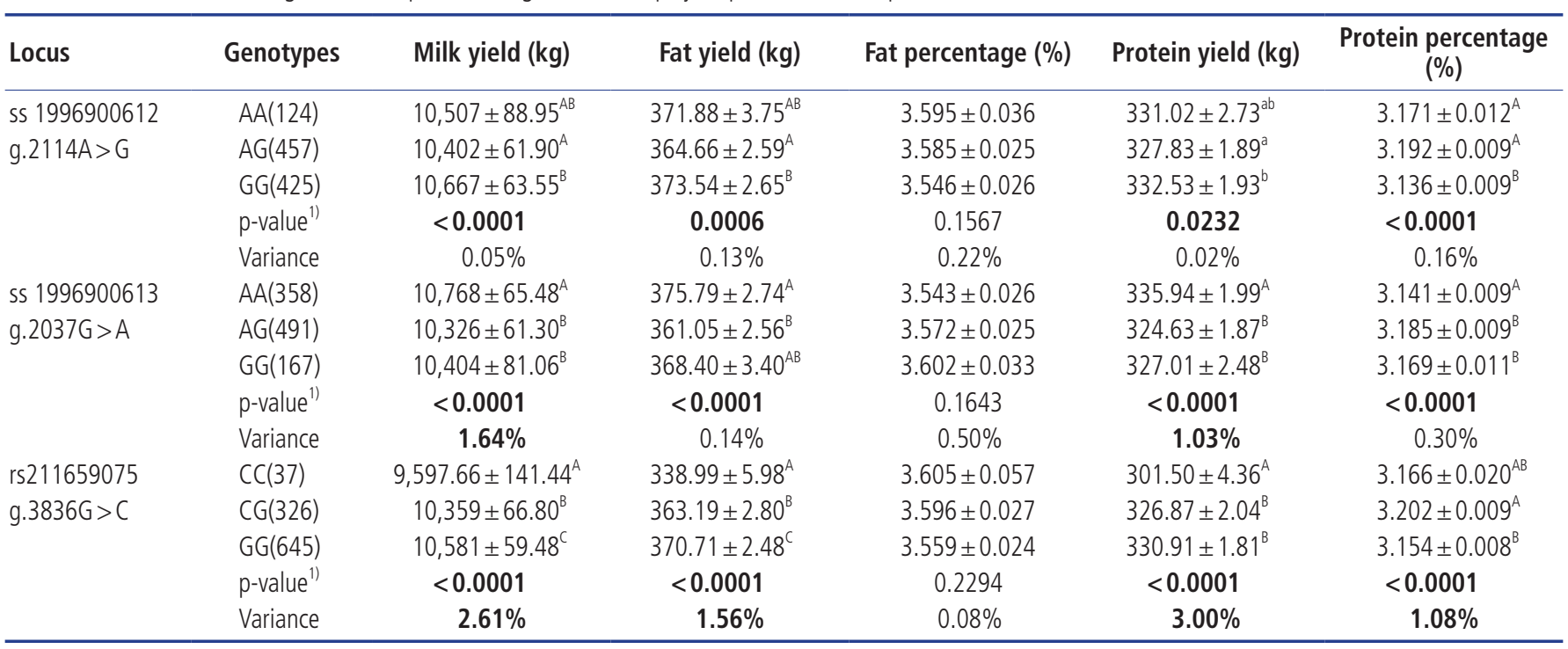

LSM, least square mean; SE, standard error; SNP, single nucleotide polymorphisms.

1) $p$-value refers to the results of association analysis between each SNP and milk production traits. Different letter (small letters, $p<0.05 ;$ capital letters, $p<0.01)$ superscripts (adjusted value after correction for multiple testing) indicate significant differences among the genotypes. Phenotypic variance ratio $=2 p(1-p) \alpha^{2} / \sigma_{p}^{2}$.

haplotypes were constructed: GAG, AGC and AGG, with frequencies of $59.8 \%, 19.8 \%$, and $15.0 \%$, respectively (Table 5). A total of six genotypes of haplotypes, $\mathrm{H} 1 \mathrm{H} 1, \mathrm{H} 2 \mathrm{H} 1, \mathrm{H} 2 \mathrm{H} 2$, $\mathrm{H} 2 \mathrm{H} 3, \mathrm{H} 3 \mathrm{H} 1$, and $\mathrm{H} 3 \mathrm{H} 3$ ( $\mathrm{H1}=\mathrm{GAG}, \mathrm{H} 2$ = AGC, H3 = AGG) were formed. Haplotype association analysis revealed consistent results with single-locus analysis (Table 6). The haplotypes $\mathrm{H} 1$ and $\mathrm{H} 3$ had higher milk yield and protein yield than $\mathrm{H} 2$ haplotype (Table 6).

\section{DISCUSSION}

Polymorphisms located in the promoter of a gene may affect transcription by altering transcription factor binding sites or RNA stability [15], which indicated the importance of the two novel SNPs (g.2114A $>$ G and g.2037G $>$ A) identified in the 5'-UTR of GALE. The intronic SNP (g.3836G>C) may have a potential regulatory effect on gene expression, regulation, transcription and mRNA splicing, although it does not hold a sequence encoding a protein [16-19]. The greater expression of GALE in mammary tissues of cows with high versus low milk protein percentage [7] agreed with such effect. To our knowledge, this was the first evidence showing significant associations of the GALE gene with milk protein traits in dairy cattle.

From a statistical standpoint, the single SNP association analysis was less powerful than multiple SNPs analysis due to the lack of simultaneous use of multiple SNPs information $[20,21]$. Thus, the haplotype-based association analysis was further performed to investigate the association of GALE variants with milk production traits in the present study. We observed that the three identified SNPs were associated with milk yield and milk protein traits, which was further con-

Table 4. Additive, dominant and allele substitution effects of the three single nucleotide polymorphisms associated with milk production traits of UDP-galactose-4epimerase in Chinese Holstein

\begin{tabular}{|c|c|c|c|c|c|c|}
\hline Locus & Genetic effect & Milk yield & Fat yield & Fat percentage & Protein yield & Protein percentage \\
\hline SS 1996900612 & Additive & $79.68 \pm 42.75$ & $-0.83 \pm 1.81$ & $0.0245 \pm 0.02$ & $-0.75 \pm 1.32$ & $0.0176 \pm 0.01 * *$ \\
\hline$g .2114 A>G$ & Dominant & $-184.83 \pm 56.79 * *$ & $-8.05 \pm 2.41 * *$ & $0.0146 \pm 0.02$ & $-3.95 \pm 1.76^{*}$ & $0.0384 \pm 0.01 * *$ \\
\hline SS 1996900613 & Additive & $182.15 \pm 39.80$ ** & $3.70 \pm 1.69^{*}$ & $-0.0295 \pm 0.02$ & $4.46 \pm 1.23^{* *}$ & $-0.0140 \pm 0.01^{* *}$ \\
\hline \multirow[t]{2}{*}{$g .2037 G>A$} & Dominant & $-259.98 \pm 52.84^{* *}$ & $-11.05 \pm 2.24^{* *}$ & $-0.0001 \pm 0.02$ & $-6.84 \pm 1.63^{* *}$ & $0.0304 \pm 0.01$ ** \\
\hline & Substitution & $133.27 \pm 43.35^{* *}$ & $1.62 \pm 1.84$ & $-0.0295 \pm 0.02$ & $3.18 \pm 1.34^{*}$ & $-0.0083 \pm 0.01$ \\
\hline g. $3836 G>C$ & Substitution & $-654.07 \pm 111.31^{* *}$ & $-20.89 \pm 4.72^{* *}$ & $0.0144 \pm 0.04$ & $-21.13 \pm 3.44^{* *}$ & $-0.0191 \pm 0.02$ \\
\hline
\end{tabular}

* Means differ at $p<0.05$. ** Means differ at $p<0.01$. 


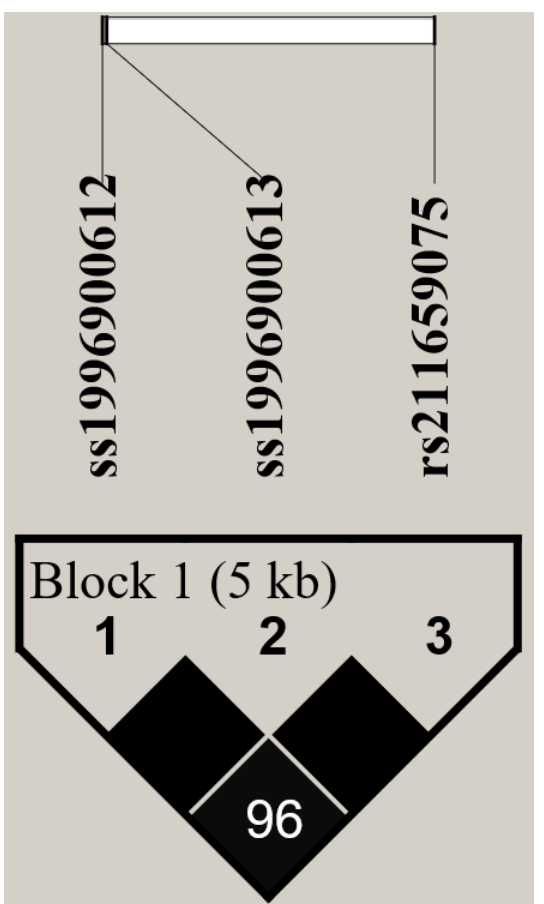

Figure 1. The haplotype blocks and pairwise linkage disequilibrium (LD) values $\left(D^{\prime}\right)$ for the UDP-galactose-4-epimerase (GALE) single nucleotide polymorphisms (SNPS). The values within boxes are pair-wise SNP correlation $\left(D^{\prime}\right)$, black boxes without numbers indicate complete $L D\left(D^{\prime}=1\right)$.

firmed by haplotype-based association analysis. Both single and haplotype association analyses demonstrated that the GALE gene was a promising candidate gene affecting milk yield and protein traits.

Protein GALE is UDP-galactose-4-epimerase, which catalyzes the interconversion of UDP-galactose and UDP-glucose in the final step of the Leloir pathway [22,23], and catalyzes the epimerization of UDP-N-acetylglucosamine to UDP$\mathrm{N}$-acetylgalactosamine [24,25]. GALE plays critical roles in dietary galactose metabolism, endogenous galactose production, and glycoprotein and glycolipid biosynthesis [26,27]. String interaction network (https://string-db.org/network/ 9606.ENSP00000363621) revealed that GALE protein interacts with LALBA, UDP-Gal: betaGlcNAc B4GALT1, and UGDH. Among this list, LALBA is the major component of milk protein and a subunit of lactose synthase. As one of the well-studied glycosyltransferases, B4GALT1 is responsible for the synthesis of complex-type N-liked oligosaccharides in many glycoproteins [8]. The association of polymorphisms of the B4GALT1 with milk production traits in Holstein cows has been reported in previously published research [9]. The $U G D H$ gene was suggested to be associated with milk yield and milk composition [10]. Taken altogether, the influences of GALE on milk production and composition are likely due to the interaction of GALE with those known genes.

\section{CONCLUSION}

Results in the present study demonstrated the significant genetic effects of GALE on milk protein traits, which is in close agreement with our previous RNA-Seq study. Results also confirmed the phenotypes of milk protein were directly af-

Table 5. Main haplotypes and their frequencies observed in GALE gene

\begin{tabular}{lcccc}
\hline GALE haplotypes & $\begin{array}{c}\text { ss1996900612 } \\
\text { A }>\text { G }\end{array}$ & $\begin{array}{c}\text { ss1996900613 } \\
\text { G>A }\end{array}$ & $\begin{array}{c}\text { rs211659075 } \\
\text { G>C }\end{array}$ & $\begin{array}{c}\text { Frequency } \\
(\%)\end{array}$ \\
\hline GAG & G & $\mathrm{A}$ & $\mathrm{G}$ & 59.8 \\
AGC & $\mathrm{A}$ & $\mathrm{G}$ & $\mathrm{C}$ & 19.8 \\
AGG & $\mathrm{A}$ & $\mathrm{G}$ & $\mathrm{G}$ & 15.0 \\
\hline
\end{tabular}

GALE, UDP-galactose-4-epimerase; SNPs, single nucleotide polymorphisms.

The Ref number of each SNP can be found in the haplotype Figure 1.

Table 6. Haplotype associations of GALE single nucleotide polymorphisms with milk production traits in Chinese Holstein cattle (LSM \pm SE)

\begin{tabular}{lccccc}
\hline GALE haplotypes & Milk yield $(\mathbf{k g})$ & Fat yield $(\mathbf{k g})$ & Fat percentage $(\%)$ & Protein yield (kg) & Protein percentage (\%) \\
\hline $\mathrm{H} 1 \mathrm{H} 1(369)$ & $10,779 \pm 66.50^{\mathrm{A}}$ & $378.16 \pm 2.78^{\mathrm{AC}}$ & $3.548 \pm 0.027$ & $336.27 \pm 2.03^{\mathrm{A}}$ & $3.140 \pm 0.009^{\mathrm{A}}$ \\
$\mathrm{H} 2 \mathrm{H} 1(243)$ & $10,403 \pm 72.46^{\mathrm{B}}$ & $362.51 \pm 3.04^{\mathrm{BD}}$ & $3.558 \pm 0.029$ & $328.14 \pm 2.21^{\mathrm{B}}$ & $3.199 \pm 0.010^{\mathrm{B}}$ \\
$\mathrm{H} 2 \mathrm{H} 2(39)$ & $9,891.26 \pm 138.99^{\mathrm{C}}$ & $350.80 \pm 5.86^{\mathrm{B}}$ & $3.611 \pm 0.056$ & $311.33 \pm 4.27^{\mathrm{C}}$ & $3.172 \pm 0.020^{\mathrm{AB}}$ \\
$\mathrm{H} 2 \mathrm{H} 3(61)$ & $10,798 \pm 118.84^{\mathrm{AD}}$ & $387.90 \pm 5.01^{\mathrm{A}}$ & $3.628 \pm 0.047$ & $341.15 \pm 3.65^{\mathrm{A}}$ & $3.175 \pm 0.016^{\mathrm{AB}}$ \\
$\mathrm{H} 3 \mathrm{H} 1(181)$ & $10,535 \pm 79.06^{\mathrm{BD}}$ & $371.77 \pm 3.31^{\mathrm{CD}}$ & $3.578 \pm 0.032$ & $331.72 \pm 2.41^{\mathrm{AB}}$ & $3.177 \pm 0.011^{\mathrm{B}}$ \\
$\mathrm{H} 3 \mathrm{H} 3(26)$ & $10,986 \pm 173.95^{\mathrm{AD}}$ & $369.53 \pm 7.35^{\mathrm{ABC}}$ & $3.405 \pm 0.070$ & $342.22 \pm 5.36^{\mathrm{AB}}$ & $3.137 \pm 0.024^{\mathrm{AB}}$ \\
p-value & $<0.0001$ & $<0.0001$ & 0.0807 & $<0.0001$ & $<0.0001$ \\
\hline
\end{tabular}

GALE, UDP-galactose-4-epimerase; LSM, least square mean; SE, standard error.

1) $p$-value refers to the results of association analysis between each haplotype and milk production traits. Different letter superscripts indicate significant differences among the haplotypes $(p<0.01)$. H1, H2, and H3 represented the types of haplotypes, of these, $H 1=G A G, H 2=A G C, H 3=A G G$. 
fected by GALE gene at genome level and transcriptional level. Due to the high phenotypic variance ratio, the SNP g.3836G $>C$ in bovine GALE may be the most promising marker implicated in milk protein concentration in dairy cattle and has the capability to be used in MAS. Hence, results lay a preliminary foundation for further identifying the causal mutations affecting milk proteins in follow-up studies.

\section{CONFLICT OF INTEREST}

We certify that there is no conflict of interest with any financial organization regarding the material discussed in the manuscript.

\section{ACKNOWLEDGMENTS}

This study was supported by the Young Talent Fund of University Association for Science and Technology in Shaanxi, China (20170202), the Key Research and Development Plan of Shaanxi Province, China (2018ZDCXL-NY-01-05), the Fundamental Research Funds for the Central Universities (2452018126), and Ph.D research start-up foundation of Northwest A\&F University (2452016203).

\section{REFERENCES}

1. Dallas DC, Murray NM, Gan JN. Proteolytic systems in milk: perspectives on the evolutionary function within the mammary gland and the infant. J Mammary Gland Biol Neoplasia 2015; 20:133-47. https://doi.org/10.1007/s10911-015-9334-3

2. Carta A, Casu S, Salaris S. Invited review: Current state of genetic improvement in dairy sheep. J Dairy Sci 2009;92: 5814-33. https://doi.org/10.3168/jds.2009-2479

3. Chen HY, Zhang Q, Yin CC, Wang CK, Gong WJ, Mei G. Detection of quantitative trait loci affecting milk production traits on bovine chromosome 6 in a Chinese Holstein population by the daughter design. J Dairy Sci 2006;89:782-90. https:// doi.org/10.3168/jds.S0022-0302(06)72140-3

4. Gebreyesus G, Lund MS, Janss L, et al. Short communication: Multi-trait estimation of genetic parameters for milk protein composition in the Danish Holstein. J Dairy Sci 2016;99: 2863-6. https://doi.org/10.3168/jds.2015-10501

5. Kolbehdari D, Wang Z, Grant JR, et al. A whole genome scan to map QTL for milk production traits and somatic cell score in Canadian Holstein bulls. J Anim Breed Genet 2009;126:21627. https://doi.org/10.1111/j.1439-0388.2008.00793.x

6. Sanchez MP, Ferrand M, Gele M, et al. Short communication: Genetic parameters for milk protein composition predicted using mid-infrared spectroscopy in the French Montbeliarde, Normande, and Holstein dairy cattle breeds. J Dairy Sci 2017; 100:6371-5. https://doi.org/10.3168/jds.2017-12663

7. Li C, Cai W, Zhou C, et al. RNA-Seq reveals 10 novel promising candidate genes affecting milk protein concentration in the Chinese Holstein population. Sci Rep 2016;6:26813. https:// doi.org/10.1038/srep26813

8. Amado M, Almeida R, Schwientek T, Clausen H. Identification and characterization of large galactosyltransferase gene families: galactosyltransferases for all functions. Biochim Biophys Acta Gen Subj 1999;1473:35-53. https://doi.org/10. 1016/S0304-4165(99)00168-3

9. Shahbazkia HR, Aminlari M, Cravador A. Association of polymorphism of the beta $(1,4)$-galactosyltransferase-I gene with milk production traits in Holsteins. Mol Biol Rep 2012; 39:6715-21. https://doi.org/10.1007/s11033-012-1495-1

10.Xu Q, Mei G, Sun DX, et al. Detection of genetic association and functional polymorphisms of $U G D H$ affecting milk production trait in Chinese Holstein cattle. BMC Genomics 2012;13:590 https://doi.org/10.1186/1471-2164-13-590

11. Barrett JC, Fry B, Maller J, Daly MJ. Haploview: analysis and visualization of LD and haplotype maps. Bioinformatics 2005; 21:263-5. https://doi.org/10.1093/bioinformatics/bth457

12. Browning SR, Browning BL. Rapid and accurate haplotype phasing and missing-data inference for whole-genome association studies by use of localized haplotype clustering. Am J Hum Genet 2007;81:1084-97. https://doi.org/10.1086/ 521987

13. Gabriel SB, Schaffner SF, Nguyen H, et al. The structure of haplotype blocks in the human genome. Science 2002;296: 2225-9. https://doi.org/10.1126/science.1069424

14. Falconer DS, Mackay TFC. Introduction to quantitative genetics, 4th edn. New York, USA: Longman Scientific and Technical; 1996.

15.Huang YZ, Li MX, Wang J, et al. A 5 '-regulatory region and two coding region polymorphisms modulate promoter activity and gene expression of the growth suppressor gene ZBED6 in cattle. Plos One 2013;8:e79744 https://doi.org/10.1371/ journal.pone.0079744

16. Nott A, Muslin SH, Moore MJ. A quantitative analysis of intron effects on mammalian gene expression. RNA 2003;9:607-17. https://doi.org/10.1261/rna.5250403

17. Park HJ, Lee S, Ju E, Jones JA, Choi I. Alternative transcription of sodium/bicarbonate transporter SLC4A7 gene enhanced by single nucleotide polymorphisms. Physiol Genomics 2017; 49:167-76. https://doi.org/10.1152/physiolgenomics.00112. 2016

18. Sagne C, Marcel V, Amadou A, Hainaut P, Olivier M, Hall J. A meta-analysis of cancer risk associated with the TP53 intron 3 duplication polymorphism (rs17878362): geographic and tumor-specific effects. Cell Death Dis 2013;4:e492 https:// doi.org/10.1038/cddis.2013.24

19. Visser M, Palstra RJ, Kayser M. Human skin color is influenced by an intergenic DNA polymorphism regulating transcription of the nearby BNC2 pigmentation gene. Hum Mol Genet 2014; 23:5750-62. https://doi.org/10.1093/hmg/ddu289 
20. Akey J, Jin L, Xiong MM. Haplotypes vs single marker linkage disequilibrium tests: what do we gain? Eur J Hum Genet 2001; 9:291-300. https://doi.org/10.1038/sj.ejhg.5200619

21. Martin ER, Lai EH, Gilbert JR, et al. SNPing away at complex diseases: Analysis of single-nucleotide polymorphisms around APOE in Alzheimer disease. Am J Hum Genet 2000;67:38394. https://doi.org/10.1086/303003

22. Daenzer JM, Sanders RD, Hang D, Fridovich-Keil JL. UDPgalactose 4'-epimerase activities toward UDP-Gal and UDPGalNAc play different roles in the development of Drosophila melanogaster. PLoS Genet 2012;8:e1002721. https:/doi.org/ 10.1371/journal.pgen.1002721

23. Schulz JM, Ross KL, Malmstrom K, Krieger M, FridovichKeil JL. Mediators of galactose sensitivity in UDP-galactose 4'-epimerase-impaired mammalian cells. J Biol Chem 2005; 280:13493-502. https://doi.org/10.1074/jbc.M414045200

24. Roper JR, Guther MLS, Milne KG, Ferguson MAJ. Galactose metabolism is essential for the African sleeping sickness parasite Trypanosoma brucei. Proc Natl Acad Sci USA 2002;99:5884-9. https://doi.org/10.1073/pnas.092669999

25. Seo A, Gulsuner S, Pierce S, et al. Inherited thrombocytopenia associated with mutation of UDP-Galactose-4-Epimerase (GALE). Hum Mol Genet 2019;28:133-42. https://doi.org/10. 1093/hmg/ddy334

26. Sanders RD, Sefton JMI, Moberg KH, Fridovich-Keil JL. UDPgalactose 4 ' epimerase (GALE) is essential for development of Drosophila melanogaster. Dis Model Mech 2010;3:628-38. https://doi.org/10.1242/dmm.005058

27.Song HB, He M, Cai ZP, et al. UDP-glucose 4-epimerase and-1,4-galactosyltransferase from the oyster Magallana gigas as valuable biocatalysts for the production of galactosylated products. Int J Mol Sci 2018;19:1600. https://doi.org/ 10.3390/ijms 19061600 